\title{
Morphological and Biochemical Characterization of Sub-Aerial Cyanobacteria Isolated from Building Facades and Monuments of Odisha
}

\author{
S. Pattnaik and L.K. Samad* \\ Department of Botany, College of Basic Science and Humanities, Orissa University of \\ Agriculture and Technology Bhubaneswar - 751003, Odisha, India \\ *Corresponding author
}

\section{Keywords \\ Cyanobacteria, Sub- aerial, Biochemical and phytochemical characterization}

\section{Article Info}

Accepted: 04 May 2018 Available Online: 10 June 2018

\section{A B S T R A C T}

Several phototrophic microorganisms, principally cyanobacteria species predominantly sheathed forms occur as biofilms on the exposed surface of stone temples, monument as well as building facades receiving areas. A study was conducted to analyse the potential of six sub-aerial cyanobacteria species belonging to three genera, i.e. Scytonema, Tolypothrix and Westiellopsis which were recorded as the main components in the biofilms isolated from 10 different sub-aerial sites (six building facades, three stone temples and one mortar monument) of Bhubaneswar and Puri, Odisha under laboratory culture conditions. The sub-aerial cyanobacteria strains were morphological characterized and changes in their biochemical constituents were analyzed in terms of total chlorophyll- $a$, total soluble protein, total carotenoids, total phycobiliproteins including phycocyanin, phycoerythrin and allophycocyanin, total cellular carbohydrate and extracellular polysaccharides in response to different time interval culture in BG-11 media. The analysis showed that maximum amount of total chlorophyll- $a$ in Scytonema hyalinum $\left(8.98 \mu \mathrm{gml}^{-1}\right)$ and minimum in Westiellopsis prolifica $\left(3.78 \mu \mathrm{gml}^{-1}\right)$. On other hand, total soluble protein content increased with incubation time and maximum amount were recorded in two species Tolypothrix rechingeri and Scytonema bohneri $\left(95.76 \mu \mathrm{gml}^{-1}\right.$ and $\left.90.76 \mu \mathrm{gml}^{-1}\right)$, while species Westiellopsis prolifica showed minimum content of soluble protein $\left(27.90 \mu \mathrm{gml}^{-1}\right)$ as compared to other strains examined. Maximum amount of total carotenoids were recorded in Tolypothrix rechingeri $\left(2.54 \mu \mathrm{gml}^{-1}\right)$ and total phycobiliproteins in Scytonema bohneri $\left(5.99 \mu \mathrm{gml}^{-1}\right)$. The results of phycobilin analysis of investigated sub-aerial cyanobacteria showed phycocyanin (PC) to be dominant phycobiliproteins with maximum value recorded in three species Tolypothrix rechingeri, Scytonema bohneri, Scytonema hyalinum and lowest in Scytonema hofman-bangii. On the contrary, Scytonema hofman-bangii recorded highest phycoerythrin $\left(2.28 \mu \mathrm{gml}^{-1}\right)$. Total cellular carbohydrate were recorded maximum during $28^{\text {th }}$ day growth in Tolypothrix rechingeri $\left(78.76 \mu \mathrm{gml}^{-1}\right)$ and minimum in Scytonema hyalinum $\left(44.9 \mu \mathrm{gml}^{-1}\right)$ whereas, the total extracellular polysaccharides contents were found to be higher in Tolypothrix rechingeri and Scytonema ocellatum on $32^{\text {th }}$ days growth $\left(64.54 \mu \mathrm{gml}^{-1}\right.$ and $58.98 \mu \mathrm{gml}^{-1}$ respectively). Study showed that Qualitative phytochemical screening of sub-aerial cyanobacteria revealed its bioactive phytochemical constituents to be alkaloids, phenol and Flavonoid etc. Acetone, methanol and chloroform are better and more efficient solvent extractors of the bioactive phytochemical constituents which vary from species to species. However, the overall response during the investigation it was observed sub-aerial cyanobacteria are prolific producers of primary and secondary metabolite(s) that may act as the antimicrobial drug resource in addition to their much explored marine and freshwater counterpart. This study is expected to contribute to data base for the drugs discovery as raw material for both biotechnological applications as well as in industrial uses for benefit of future generation. 


\section{Introduction}

Cyanobacteria are considered as one of the potential source of both primary and secondary metabolites. They are cosmopolitian in nature and are found in both filamentous and coccoid forms occupying mostly tropical climate than temperate zones. These autotropic organism can withstand harsh and extreme conditions like extreme temperature, drought, U.V radiations etc. thus can grow on exposed walls of building facades, temples and monuments. During last decades, these gram negative, photosynthetic prokaryotes are considered to be the pioneer microorganisms inhabiting the exposed surface of most building facades and monuments across the length and breadth of the world (Rossi et al., 2012; Keshari and Adhikary, 2014; Adhikary et al., 2015). Cyanobacteria secrete some exopolymeric substances (EPS) which help them to grow in association with other microorganisms like bacteria, fungus, actinomycetes by forming biofilms on the exposed walls of building facades and monuments (Rossi et al., 2012). They play an important role in reducing the a number of microorganisms like bacteria, fungus and viruses thus showing antimicrobial activity against them (Gutierrez et al., 2008; Asthana et al., 2009). Cyanobacteria are rich source of a number of primary metabolites like proteins, carbohydrates, amino acids, pigments which can be used as dietary supplements, as well as industrial application. Among microorganisms, cyanobacteria are rapidly proving to be an extremely important source of biologically active secondary metabolites like alkaloids, phenol compounds, saponin, tannins etc. have wide spread applications in pharmaceutical industries against many human diseases. Recent trends in drug research from natural sources suggest that cyanobacteria are excellent sources to provide novel biochemically active constituents produced during primary and especially secondary metabolism (Skulberg, 2000) with varied application which are useful to mankind in various ways.

In spite of having such wide spread importance in the field of biotechnology, cyanobacteria have received less importance as compared to viruses, bacteria and fungus. Therefore, the objective of our study was to make an exploratory analysis about biochemical and phytochemical composition of six sub-aerial cyanobacteria possessing well developed sheath layers around their trichome found typically in sub-aerial habitats. In addition, we compared our results with other studies in an attempt to contribute to current researches about economic value of sub-aerial cyanobacteria and, if warranted, to recommend its use for human activities.

\section{Materials and Methods}

Microbial biofilms were collected from horizontal and vertical surfaces of 10 subaerial sites including six building facades, three stone temples and one mortar monuments of Orissa state but principally from Bhubaneswar (Temperature: $21^{\circ} \mathrm{C}$, Latitude /Longitude: $20^{\circ} 25^{\prime} 36.82^{\prime} \mathrm{N}$ and $85^{\circ}$ $48^{\prime} 10^{\prime} \mathrm{E}$ ) and Puri cities (Temperature: $21^{\circ} \mathrm{C}$, Latitude /Longitude: $20^{\circ} 25^{\prime} 36.82^{\prime \prime} \mathrm{N}$ and $85^{\circ}$ $48^{\prime} 10^{\prime}$ 'E) during monsoon and post monsoon period. Sample collection included substrates like composites (limestone, sandstone, stone, cement, concrete, brick and rock), painted surfaces (lime-washed over concrete or mortar) and dimensional stone of both calcareous and siliceous types of building including monuments and temple soon after monsoon rain and post monsoon seasons, and stored in pre-sterilized sampling bottles. The biofilms were soaked in sterile distilled water and incubated under fluorescent light for up to $72 \mathrm{~h}$ and observed microscopically. Since the morphological features needed for identification were not distinct even after 
prolonged soaking (up to 7 to 10 days), a small amount of sample were transferred to BG -11 agar plates medium with and without nitrogen (Rippka et al., 1979) (1.5\%w/v agar in same medium) with the help of inoculation needle. Cultures were incubated at $28 \pm 2{ }^{\circ} \mathrm{C}$ under continuous light from fluorescent tubes at an intensity of 2000lux. After a period of 10 to 14 days of incubation, cyanobacteria appeared in the culture were isolated and maintained in the laboratory. The cultures were microscopically examined using inverted microscope, and identified by following standard monographs (Desikachary, 1959; Komárek and Hauer, 2015). Total six subaerial cyanobacteria strains were isolated i.e Scytonema ocellatum (cement surface, Building facades), Scytonema hofman-bangii (stone, Building facades), Scytonema hyalinum (rock surface, Temple), Scytonema bohneri (mortar, monument), Westellopsis prolifica (cement and stone surface, Building facades and temples) and Tolypothrix rechingeri (stone carving, Temple), and sub cultured to $50 \mathrm{ml}$ of culture media in $100 \mathrm{ml}$ conical flasks, and incubated under illumination of 2000lux with 16:8h light and dark regime, using cool fluorescent tubes. Cultures were uniformly stirred twice for 3-5 minutes every day to prevent cell clumping.

Three replicas of each test tubes containing $9 \mathrm{ml}$ aliquots of sterile $\mathrm{BG}-11$ liquid medium (with and without nitrogen) were inoculated with $1 \mathrm{ml}$ stock culture with inoculums of the isolated strain and were maintained for zero day, $4^{\text {th }}, 8^{\text {th }}, 12^{\text {th }}, 16^{\text {th }}, 20^{\text {th }}, 24^{\text {th }}, 28^{\text {th }}, 32^{\text {th }}, 36^{\text {th }}$ and $40^{\text {th }}$ day's analysis. Cells were harvested at 4 day interval during growth, specific amount of culture was withdrawn from each test tube and analysed for the chlorophyll- $a$ by the standard methods of McKinney (1941), carotenoids pigment by (Jensen, 1978) and phycobiliprotein including $\mathrm{PC}, \mathrm{PE}$ and $\mathrm{APC}$ were estimated by the methods of Bennett and Bogorad (1973). Total soluble protein was estimated by the method of Lowry et al., (1951). Total cellular carbohydrates and released extracellular polysaccharides (EPSs) were estimated by anthrone reagent (Herbert et al., 1971). All the experiments were conducted in triplicates. Mean value of 3 replicates of each experiment \pm S.D has been presented in the text. The absorbance was measured using Systronics UV - visible spectrophotometer.

After 28days of incubation, biomass was harvested through Buchner funnel with Whatman No.1 filter paper and dried in shade for 30 minutes in hot air oven and grinded to fine powder with the help of glass homogenizer and finally weighed. $1 \mathrm{gms}$ of the powdered samples of each isolates were extracted with aqueous and using different organic solvents such as hexane, benzene, chloroform, methanol and acetone using soxhlet apparatus for 48 hours maintaining at temperature $45^{\circ} \mathrm{C}$. The each crude extracts were collected separately in air tight containers, and finally were stored at $4{ }^{\circ} \mathrm{C}$ for phytochemical analysis. To detect different phytoconstituents present in the extracts, experiments were conducted following the standard of Dragendorff's test and Mayer's test; Ferric chloride test and Lead Acetate test; Alkaline Reagent test; Quinone test; Libermann Burchard test, Borntrager's test, Terpenoids test and Coumarin test etc.

\section{Results and Discussion}

Bhubaneswar $\left(20^{\circ} 15^{\prime} \mathrm{N}\right.$ and $\left.85^{\circ} 50^{\prime} \mathrm{E}\right)$ and Puri (19 38' 59. 63" $\mathrm{N}$ and $85^{\circ} 50^{\prime} 23.52$ " E) of Odisha has occupied a unique position among different states of India for ancient sandstone temples, old and modern monuments as well as building facades. The sides exposed to direct sunlight were colonized by microorganisms that have produced microbial biofilms appeared with blackishbrown/blackish green/ brownish or bluish- 
green etc., were mainly dominated with cyanobacteria as compared to other organisms. Such sub-aerial cyanobacteria occurring in the biofilms on the horizontal as well as vertical surface of 10 different sub-aerial sites were sampled during monsoon and post monsoon period. Totally, six species of cyanobacteria were recorded as major component in biofilms/crusts possess well developed sheath layers around their trichome given in Table 1 and Figure 1. Out of the 6 species of cyanobacteria, three species of cyanobacteria were isolated from building facades e.g. Scytonema ocellatum, Scytonema hofmanbangii and Westellopsis prolifica, whereas two species from temple e.g. Scytonema hyalinum, Tolypothrix rechingeri and other from monument Scytonema bohneri identified using different monographs and research publications: Desikachary (1959), Komárek and Hauer (2015), Keshari and Adhikary (2014).

Six isolates from three genera viz-a-viz, Scytonema ocellatum, Scytonema hofmanbangii, Scytonema hyalinum, Scytonema bohneri, Tolypothrix rechingeri and Westellopsis prolifica are summarised in (Table 1 and Fig. 1) were grown in nitrogen free $\mathrm{BG}-$ II media at $28 \pm 2^{\circ} \mathrm{C}$ under continuous light provided by day light fluorescent tube at a light intensity of 2000lux and harvested at 4 day interval up to $40^{\text {th }}$ day for biochemical analysis such as chlorophyll- $a$ and soluble protein, carotenoid, total PBPs including phycocyanin, phycoerythrin and allophycocyanin, cellular carbohydrate and released extracellular polysaccharides content shown in Figure 2-4(a-f).

Cyanobacteria are recognized as an excellent source of natural pigments (Dufossé et al., 2005). The chlorophyll is the primary photosynthetic pigments in all microalgae species and they also produce various accessory or secondary pigments, such as
PBPs and a wide range of carotenoids (Gouveia et al., 2008). In the present study, highest chlorophyll- $a$ and soluble protein contents increased with increased incubation time in all species. The maximum chlorophyll$a$ and soluble protein content was accumulated from $8^{\text {th }}$ to $28^{\text {th }}$ day in all the sub-aerial cyanobacteria strains. Results showed that total chlorophyll- $a$ content of the isolates ranged from $\left(1.67-7.78 \mu \mathrm{gml}^{-1} ; 1.19-\right.$ $7.66 \mu \mathrm{gml}^{-1} ; \quad 1.30-8.98 \mu \mathrm{gml}^{-1} ; 1.26-$ $6.24 \mu \mathrm{gml}^{-1} ; 2.72-6.84 \mu \mathrm{gml}^{-1}$ and $1.19-$ $3.78 \mu \mathrm{gml}^{-1}$ ) with incubation time as it attained maximum peak value on $28^{\text {th }}$ day, only minor reduced amount were noted on $40^{\text {th }}$ day showed in Figure 2(a-f). Scytonema hyalinum Gardner $\left(8.98 \mu \mathrm{gml}^{-1}\right) \quad$ showed highest chlorophyll- $a$ content with comparison to other on $28^{\text {th }}$ day of growth (Fig. 2c), followed by Scytonema ocellatum, Scytonema hofmanbangii and Tolypothrix rechingeri. The chlorophyll-a content of Scytonema tolyprothrichoides isolated from rice field reported by Deb et al., (2015) were higher than the value obtained in the present study which was $4.94 \mathrm{mgml}^{-1}$. The chlorophyll- $a$ content of all isolates showed equal value or falls within the ranges as recorded from freshwater, marine and terrestrial habitats (Becker, 1994; Rai and Rajashekhar, 2015; Paul and Rout, 2017). The study conducted by Balder et al., (2006) and Ferruzzi and Blakesee, (2007) has provided evidence linking chlorophyll consumption to a decreased risk of colorectal, and its derivatives can exhibit health-promoting activities and these compounds have traditionally used in medicine due to its wound healing and antiinflammatory properties. Total soluble protein content showed a gradually increase from their initial incubation day to $28^{\text {th }}$ day and then decreased as nitrogen became limiting. It was Tolypothrix rechingeri followed by Scytonema bohneri which exhibit maximum amount of soluble protein content $\left(95.76 \mu \mathrm{gml}^{-1}\right.$ and $90.76 \mu \mathrm{gml}^{-1}$ respectively), followed by 
Scytonema ocellatum, S. hofman-bangii, S. hyalinum and Westiellopsis prolifica $\left(77.98 \mu \mathrm{gml}^{-1} ; 76.90 \mu \mathrm{gml}^{-1} ; 72.09 \mu \mathrm{gml}^{-1}\right.$ and $27.90 \mu \mathrm{gml}^{-1}$ ). Upon exposure to $40^{\text {th }}$ day of incubation, the value of soluble protein showed slightly decreased by $28.12 \mu \mathrm{gml}^{-1}$, $67.23 \mu \mathrm{gml}^{-1}, \quad 62.90 \mu \mathrm{gml}^{-1}, \quad 82.12 \mathrm{gml}^{-1}$, $91.12 \mu \mathrm{gml}^{-1}$ and $17.23 \mu \mathrm{gml}^{-1}$ in four species of Scytonema, Tolypothrix and Westiellopsis. In Tolypothrix strain including four species of Scytonema, there were tendencies toward increased soluble protein content which could be due to the fact that they adapt to such habitats exposed to extreme temperature or deprivation of nutrients resulting in signaling the synthesis of new proteins which contribute to the survival of the organisms (Pandey, 2006). However, soluble protein content varied significantly with increase incubation time as well as amount content of chlorophyll. However, all of them could grow and synthesis the pigments and protein at a reduced rate than that of the control. The studies reported by Tonetto et al., (2014) showed total lipid, protein, carbohydrate and gross fibres values for $L$. majuscula, $S$. delicatula and Oedogonium sp. L. majuscula displayed the highest values of protein and gross fibre content $\left(264.73 \mathrm{~g} \mathrm{Kg}^{-1}\right.$ and 194.40 $\mathrm{g} \mathrm{Kg}^{-1}$, respectively).

High protein content was registered for other cyanobacteria species (Gantar and Svircev, 2008). Some studies reported Spirullina and Nostoc commune contains highest amount of protein and fibre that make it an important component of human diet. Scytonema and Tolypothrix, although its lower protein content in comparison to L. majuscula, Spirullina and Nostoc commune isolated from stream system but it presented almost equal values of protein in ranges than those found for freshwater algae and marine red algae (Ciferri and Tiboni, 1985; Rajeshwari and Rajashekhar, 2011; Gressler et al., 2011), which have been used in a variety of foods throughout the world (Gantar and Svircev, 2008). Thus, Tolypothrix and Scytonema followed by other species examined could be more studied to become an option of fibres source to healthy food industry after proper scientific investigation. The changes in the pigment composition and soluble protein of all the six organisms with incubation duration followed almost a similar trend like that of their growth response. This result shows that the sub-aerial cyanobacteria have a great potential for economic application and deserve more attention.

Apart from chlorophyll, two major groups of secondary pigments (carotenoids and phycobiliproteins) were also examined in all six strains isolates. The study of Hertzberg et al., (1971) reported that carotenoids composition of Anabaena flos-aquae and three other species of Phormidium showed the presence of $\beta$-carotene as the major carotenoids in all studied. Hence, in cyanobacteria the most abundant carotenoids are carotenes (e.g., $\beta$-carotene), act in prevention of photo-oxidative damage (Nishiyama and Murata, 2014) and also protect against age related diseases (Takaichi, 2011).

Some studies reported a variety of carotenoids and their important commercial uses such as colouring agents in food industry, dietary supplements in the field of poultry and aquaculture, as well as for use in cosmetics due to non-toxic in nature (Enzing et al., 2014). In present study, total carotenoids content was found maximum during $28^{\text {th }}$ day of growth. Tolypothrix rechingeri $(2.54 \mu \mathrm{g}$ $\mathrm{ml}^{-1}$ ) showed highest carotenoids content with comparison to other on $28^{\text {th }}$ day followed by Scytonema bohneri $\left(2.12 \mu \mathrm{gml}^{-1}\right)$. The carotenoids production in the remaining four species examined, carotenoids content ranged from $1.05-1.98 \mu \mathrm{gml}^{-1}$ respectively represented in Figure 2a-f. 
Table.1 Detail of cultural studies and their taxonomical characterization of the sub-aerial cyanobacteria isolates

\begin{tabular}{|c|c|c|c|c|}
\hline $\begin{array}{l}\text { Sl. } \\
\text { No. }\end{array}$ & Major Organisms in Biofilms & $\begin{array}{l}\text { Habitat with Geographical } \\
\text { details }\end{array}$ & Taxonomical Studies & Voucher no. \\
\hline 1. & $\begin{array}{l}\text { Scytonema ocellatum (Lyngbye) } \\
\text { Bornet \& Flahault [Synonym: } \\
\text { Scytonema cinereum Meneghini } \\
\text { 1837; Scytonema murale Zeller } \\
\text { 1873] }\end{array}$ & $\begin{array}{l}\text { Occurred as brownish crust on } \\
\text { sandstone, Building facades, } \\
\text { Bhubaneswar, Odisha } \\
\text { Temperature: } 21^{\circ} \mathrm{C} \\
\text { Latitude } / \text { Longitude: } \\
\mathbf{2 0}^{\circ} \mathbf{2 5} \mathbf{3 6 . ~}^{\circ} \mathbf{8 2}^{\mathbf{0}} \mathbf{8 5 ^ { \circ }} \mathbf{4 8}^{\prime} \mathbf{1 0}^{\mathbf{0}} \mathbf{E}\end{array}$ & $\begin{array}{l}\text { Thallus expanded, greyish blue; } \\
\text { filaments } 10-16.5 \mu \mathrm{m} \text { broad, erect, } \\
\text { false branched, less constricted at } \\
\text { the cross walls; sheath firm; } \\
\text { trichome } 6-14 \mu \mathrm{m} \text { broad; apical cell } \\
\text { rounded; heterocyst sub-quadrate or } \\
\text { cylindrical to discoid, yellowish, } \\
12-13.2 \mu \mathrm{m} \text { broad, } 9.9-12 \mu \mathrm{m} \text { long. }\end{array}$ & $\begin{array}{l}\mathrm{BOT} / \mathrm{UAT}- \\
82\end{array}$ \\
\hline 2. & $\begin{array}{l}\text { Scytonema hofman- bangii } \\
\text { Agardh ex Silva } \\
\text { [Synonym: Scytonema hofmanni } \\
\text { C. Agardh ex Bornet and Flahault } \\
\text { 1887] }\end{array}$ & $\begin{array}{l}\text { Occurred as brownish crust on } \\
\text { stone surface, Building Facades, } \\
\text { Bhubaneswar, Odisha } \\
\text { Temperature: } 21^{\circ} \mathrm{C} \\
\text { Latitude /Longitude: } \\
\mathbf{2 0}^{\circ} \mathbf{2 5} \mathbf{3 6 . 8 2}^{\prime} \mathbf{N} \mathbf{8 5}^{\circ} \mathbf{4 8} \text { ' }^{\prime} \text { " E }\end{array}$ & $\begin{array}{l}\text { Thallus olive to blue green; } \\
\text { filament long, false branched, } \\
\text { aggregated in vertical fascicles; } \\
\text { cells unequal in length, } 7.7-14.3 \\
\mu \mathrm{m} \text { broad, } 4.0-5.5 \mu \mathrm{m} \text { long,; } \\
\text { heterocyst oblong. }\end{array}$ & BOT/UAT - 81 \\
\hline 3. & $\begin{array}{l}\text { Scytonema hyalinum Gardner } \\
1927\end{array}$ & $\begin{array}{l}\text { Occurred as blackish mats on } \\
\text { rock surface, } \\
\text { Bhubaneswar, Odisha } \\
\text { Temperature: } 31^{\circ} \mathrm{C} \\
\text { Latitude /Longitude: } \\
\mathbf{2 0}^{\circ} \mathbf{1 5} \mathbf{8 6 . 8 8}^{\prime} \mathbf{N} \mathbf{8 5} \mathbf{8 4}^{\prime} \mathbf{3 9}^{\prime} \text { ' E }\end{array}$ & $\begin{array}{l}\text { Thallus blue-green; filaments } \\
\text { densely entangled, cylindrical } 10- \\
15 \mu \mathrm{m} \text { broad, } 1.5-2.5 \mu \mathrm{m} \text { long, } \\
\text { young branches usually constricted } \\
\text { at cross walls; trichomes mostly } 4.6 \\
-12 \mu \mathrm{m} \text { wide; cells shorter than } \\
\text { wide up to rarely isodiametric, cell } \\
\text { at the apex slightly barrel shaped; } \\
\text { sheath firm, thin and slightly } \\
\text { lamellated; terminal cell yellowish; } \\
\text { heterocyst intercalary, cylindrical or } \\
\text { barrel shaped with rounded ends, } \\
\text { yellowish, } 8.5-12 \mu \mathrm{m} \text { broad. }\end{array}$ & $\begin{array}{l}\text { BOT/ UAT - } \\
72\end{array}$ \\
\hline 4. & Scytomema bohneri Schmidle & $\begin{array}{l}\text { Occurred as greenish mats on } \\
\text { mortar, Monument, } \\
\text { Bhubaneswar, Odisha } \\
\text { Temperature: } 34^{\circ} \mathrm{C} \\
\text { Latitude /Longitude: } \\
\mathbf{2 0}^{\circ} \mathbf{2 8} \mathbf{9 0 . 2 8}^{\prime} \mathbf{N} \mathbf{8 5}^{\circ} \mathbf{8 1} \mathbf{~ 3 3}^{\prime} \mathbf{E}\end{array}$ & $\begin{array}{l}\text { Thallus blue-green; filaments long, } \\
7.5 \text { - } 15 \mu \mathrm{m} \text { broad, } 2.5-9 \mu \mathrm{m} \text { long, } \\
\text { cells shorter than wide up to rarely } \\
\text { isodiametric, cell at the apex } \\
\text { slightly barrel shaped; binary false } \\
\text { branching; sheath slightly } \\
\text { thickened; heterocyst intercalary, } \\
\text { cylindrical or barrel shaped, } \\
\text { yellowish, } 8.5 \text { - } 10 \mu \mathrm{m} \text { broad. }\end{array}$ & $\begin{array}{l}\text { BOT/ UAT } \\
62\end{array}$ \\
\hline 5. & $\begin{array}{l}\text { Tolypothrix rechingeri (Wille) } \\
\text { Geitler }\end{array}$ & 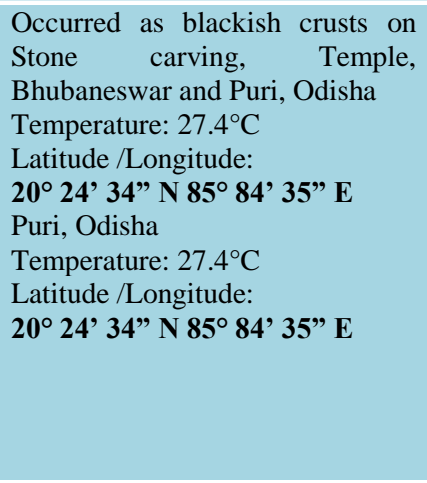 & $\begin{array}{l}\text { Thallus brownish, wooly; } \\
\text { filaments straight, sometimes } \\
\text { curved, false branched; false } \\
\text { branch short, many; cells barrel } \\
\text { shaped, broader than long, 9.2- } 16 \\
\mu \text { rn broad, } 6.9-9.2 \mu \mathrm{m} \text { long, } \\
\text { trichome constricted at the cross } \\
\text { walls; heterocyst both basal and } \\
\text { intercalary, sub-spherical to barrel } \\
\text { shaped, sub-spherical when board } \\
\text { and barrel shaped when } \\
\text { intercalary, } 11.5-13.8 \mu \mathrm{m} \text { broad, } \\
4.6-11.5 \mu \mathrm{m} \text { long; sheath yellowish- } \\
\text { brown, } 2.3-4.6 \mu \mathrm{m} \text { thick. }\end{array}$ & $\begin{array}{l}\text { BOT/UAT - } 07 \\
\text { BOT/UAT - } 46 \\
\& 48\end{array}$ \\
\hline 6. & Westiellopsis prolifica Janet & $\begin{array}{l}\text { Occurred as greenish patch on } \\
\text { cement wall surface and stone } \\
\text { surface, Building facades and } \\
\text { Temple, Bhubaneswar and Puri, } \\
\text { Odisha } \\
\text { Temperature: } 31^{\circ} \mathrm{C} \\
\text { Latitude /Longitude: } \\
\mathbf{2 0}^{\circ} \mathbf{1 5} \mathbf{8 6}^{\circ} \mathbf{8 8} \mathbf{N ~ 8 5}^{\circ} \mathbf{8 4} \mathbf{3 9}^{\prime} \text { ' E }\end{array}$ & $\begin{array}{l}\text { Thallus blue green; filament with } \\
\text { prostrate and erect branches, lateral } \\
\text { branch thinner than main branch, } 6 \\
-7 \mu \mathrm{m} \text { broad, } 9-12 \mu \mathrm{m} \text { long; cell } \\
\text { spherical or elliptical } 5-6 \mu \mathrm{m} \\
\text { diameter; heterocyst intercalary, } \\
\text { light yellow, rectangular, } 4-6 \mu \mathrm{m} \\
\text { broad, } 8-10 \mu \mathrm{m} \text { long. }\end{array}$ & $\begin{array}{c}\text { BOT/ UAT - } \\
08 \\
\text { BOT/ UAT - } \\
73\end{array}$ \\
\hline
\end{tabular}


Table.2 Clearly indicate the presence of phytochemical constituents present in the aqueous and five different extracts

\begin{tabular}{|c|c|c|c|c|c|c|c|c|c|c|}
\hline & & \multicolumn{9}{|c|}{ Phytochemical constituents } \\
\hline 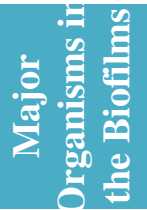 & 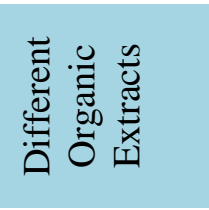 & $\begin{array}{l}\frac{0}{0} \\
\frac{0}{\pi} \\
\frac{\pi}{2}\end{array}$ & 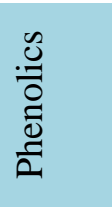 & 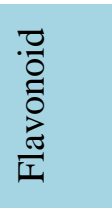 & 㫄 & $\begin{array}{l}\frac{0}{0} \\
\frac{0}{0} \\
\frac{0}{0} \\
0\end{array}$ & $\begin{array}{l}\frac{0}{0} \\
0 \\
0 \\
0 \\
0 \\
0\end{array}$ & 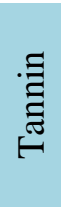 & $\frac{\tilde{0}}{\frac{0}{0}}$ & ن \\
\hline \multirow[t]{6}{*}{1.} & Aqueous & & & & & & & & & \\
\hline & Hexane & + & + & + & & & & & & \\
\hline & Benzene & + & + & + & + & & & & & \\
\hline & Chloroform & ++ & ++ & + & & + & & & & \\
\hline & Acetone & ++ & ++ & + & + & + & & & & \\
\hline & Methanol & ++ & ++ & + & & & & & & \\
\hline \multirow[t]{6}{*}{2.} & Aqueous & & & & & & & & & \\
\hline & Hexane & + & + & + & & + & & & & \\
\hline & Benzene & + & + & + & + & + & & & & \\
\hline & Chloroform & ++ & + & ++ & & & & & & \\
\hline & Acetone & ++ & ++ & ++ & ++ & + & & & & \\
\hline & Methanol & +++ & ++ & + & ++ & & & & & \\
\hline \multirow[t]{6}{*}{3.} & Aqueous & & & & & & & & & \\
\hline & Hexane & + & + & + & & & & & & \\
\hline & Benzene & + & + & + & & & & & & \\
\hline & Chloroform & ++ & ++ & + & + & & & & & \\
\hline & Acetone & +++ & ++ & ++ & + & + & & & & \\
\hline & Methanol & ++ & ++ & ++ & ++ & & & & & \\
\hline \multirow[t]{6}{*}{4.} & Aqueous & & & & & & & & & \\
\hline & Hexane & + & + & ++ & & & & & & \\
\hline & Benzene & + & + & ++ & & & & & & \\
\hline & Chloroform & ++ & ++ & ++ & & & & & & \\
\hline & Acetone & +++ & ++ & ++ & + & & & & & \\
\hline & Methanol & +++ & ++ & ++ & + & & & & & \\
\hline \multirow[t]{6}{*}{5.} & Aqueous & & & & & & & & & \\
\hline & Hexane & + & + & ++ & & & & & & \\
\hline & Benzene & + & + & + & & & & & & \\
\hline & Chloroform & + & +++ & ++ & & + & & & & \\
\hline & Acetone & +++ & ++ & ++ & + & + & & & & \\
\hline & Methanol & +++ & +++ & +++ & + & & & & & \\
\hline \multirow[t]{6}{*}{6.} & Aqueous & & & & & & & & & \\
\hline & Hexane & + & + & + & & & & & & \\
\hline & Benzene & + & + & + & & & & & & \\
\hline & Chloroform & +++ & +++ & +++ & & & & & & \\
\hline & Acetone & +++ & ++ & ++ & + & & & & & \\
\hline & Methanol & +++ & +++ & +++ & & & & & & \\
\hline
\end{tabular}

Major Organisms in Biofilms: 1. Scytonema ocellatum, 2. Scytonema hofman-bangii, 3. Scytonema hyalinum, 4. Scytonema bohneri, 5. Tolypothrix rechingeri and 6. Westiellopsis prolifica.

Keys: $+++=$ indicate positive response with highest concentration; $++=$ indicate positive response with high concentration and $+=$ indicates presence with low concentration. 
Fig.1 Major species of sub-aerial cyanobacteria isolated from the exterior surface of the ten different sub-aerial sites (building facades, temple and monuments) in Bhubaneswar and Puri, Odisha. Building facades: (a) within $72 \mathrm{~h}$ of wetting the biofilm; (b) Scytonema ocellatum, which appeared in a culture of the same biofilm sample; Building facades: (c) within $72 \mathrm{~h}$ of wetting the biofilm, (d) Scytonema hofman-bangii, which appeared in a culture of the same biofilm sample; Temple: (e) within 72h of wetting the biofilm; (f) Scytonema hyalinum, which appeared in a culture of the same biofilm sample. Monument: (g) within $72 \mathrm{~h}$ of wetting the biofilm; (h) Scytonema bohneri, which appeared in a culture of the same biofilm sample. Temple: (i) within $72 \mathrm{~h}$ of wetting the biofilm; (j) Tolypothrix rechingeri, which appeared in a culture of the same biofilm sample. Building facades and Temple: (k) within $72 \mathrm{~h}$ of wetting the biofilm; and (l) Westiellopsis prolifica, which appeared in a culture of the same biofilm sample. Scale bars $=20 \mu \mathrm{m}$

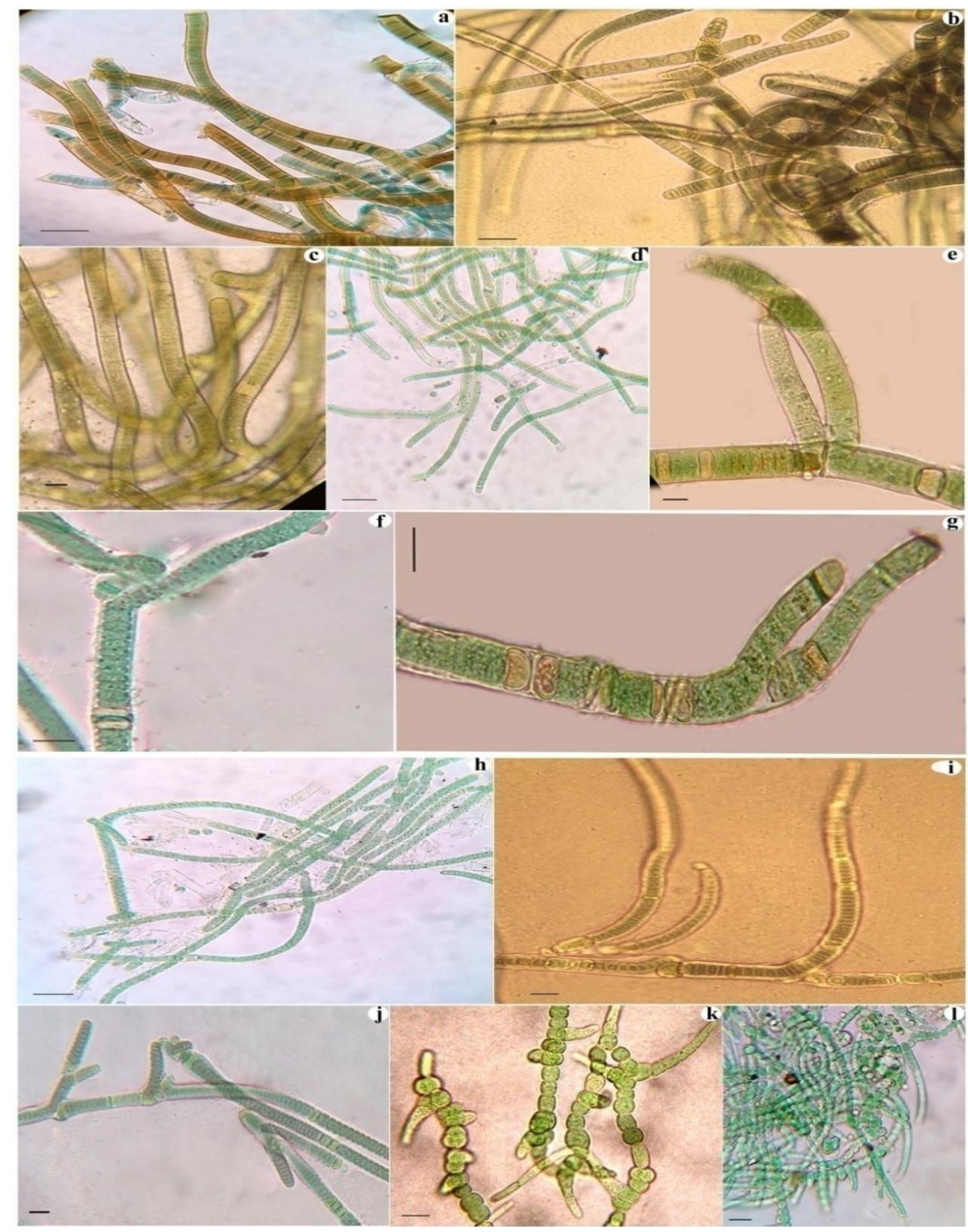


Fig.2 Graph showing temporal variations of chlorophyll and soluble protein content in following sub-aerial Cyanobacteria species (a) Scytonema ocellatum; (b) Scytonema hofman-bangii; (c) Scytonema hyalinum; (d) Scytonema bohneri; (e) Tolypothrix rechingeri; and (f) Westiellopsis prolifica. Data are mean values \pm SD $(n=3)$

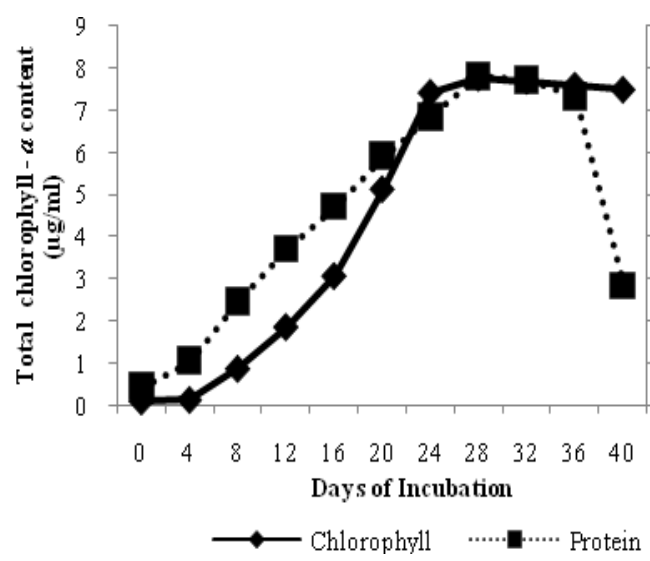

(a)

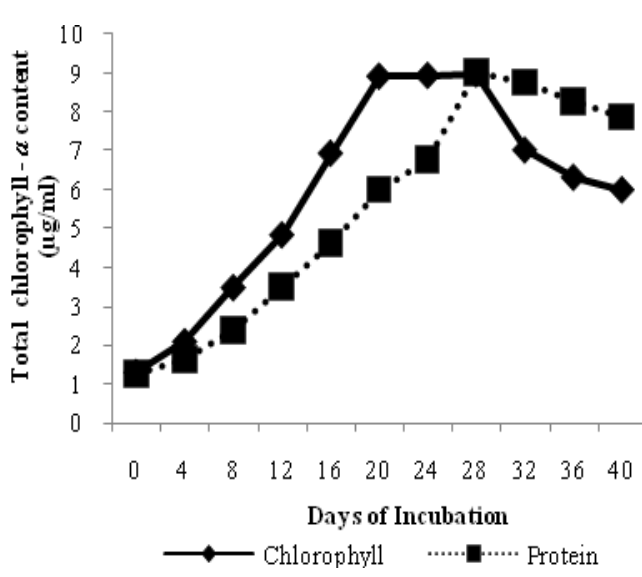

(c)

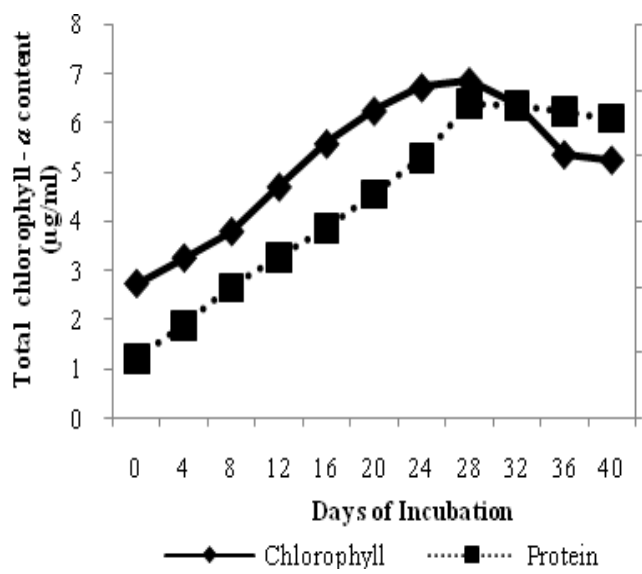

(e)

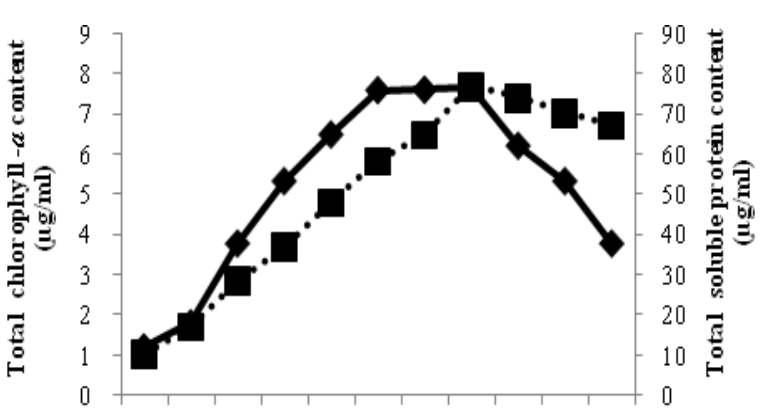

$\begin{array}{lllllllllll}0 & 4 & 8 & 12 & 16 & 20 & 24 & 28 & 32 & 36 & 40\end{array}$ Days of Incubation

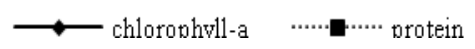

(b)
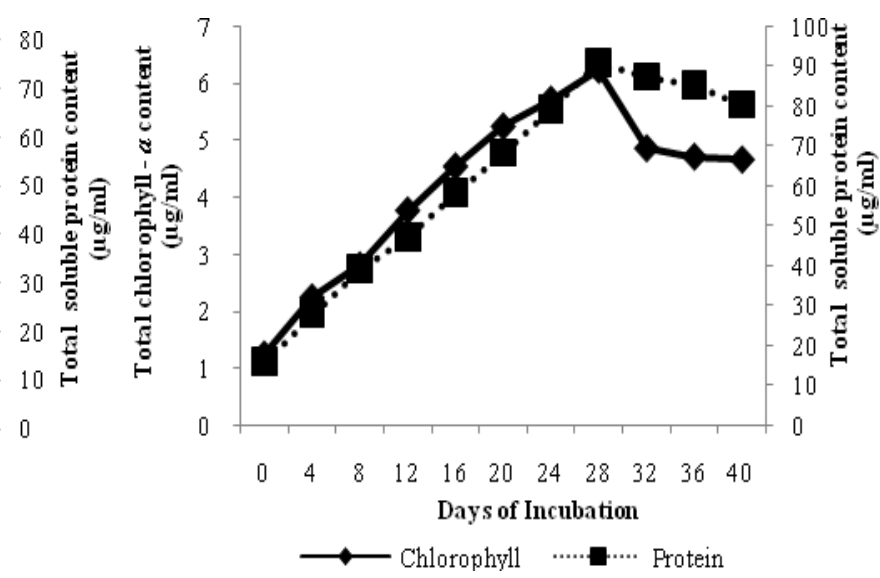

(d)
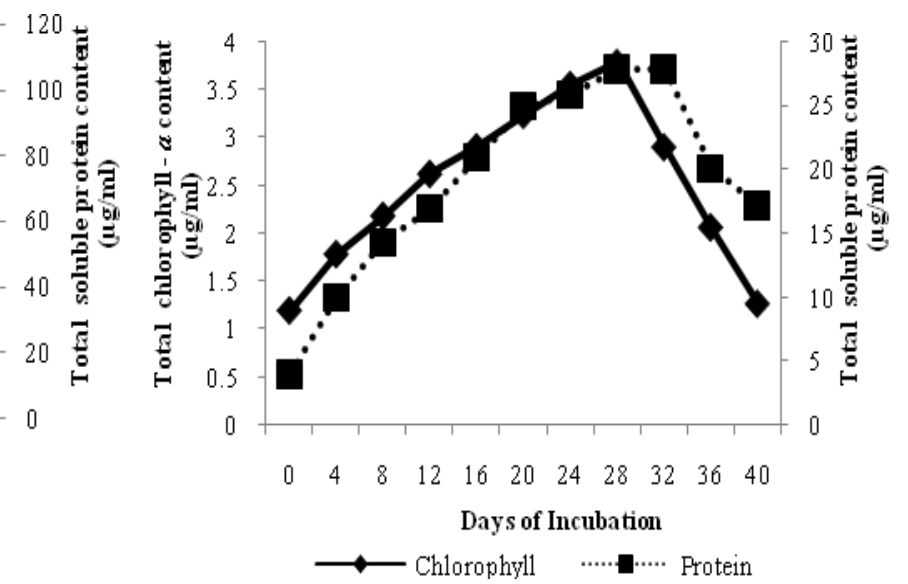

(f) 
Fig.3 Graph showing temporal variations of carotenoids, phycoerythrin, phycocyanin and allophycocyanin content in following sub-aerial Cyanobacteria species (a) Scytonema ocellatum; (b) Scytonema hofman-bangii; (c) Scytonema hyalinum; (d) Scytonema bohneri; (e) Tolypothrix rechingeri; and (f) Westiellopsis prolifica. Data are mean values \pm SD $(n=3)$

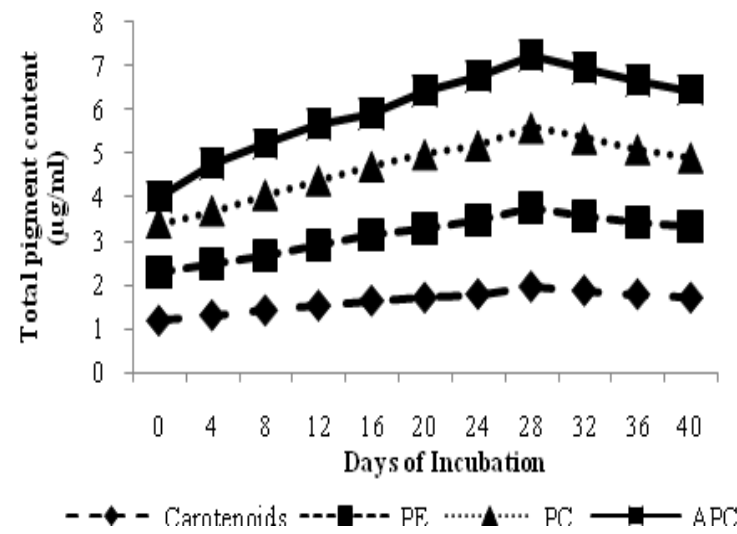

(a)

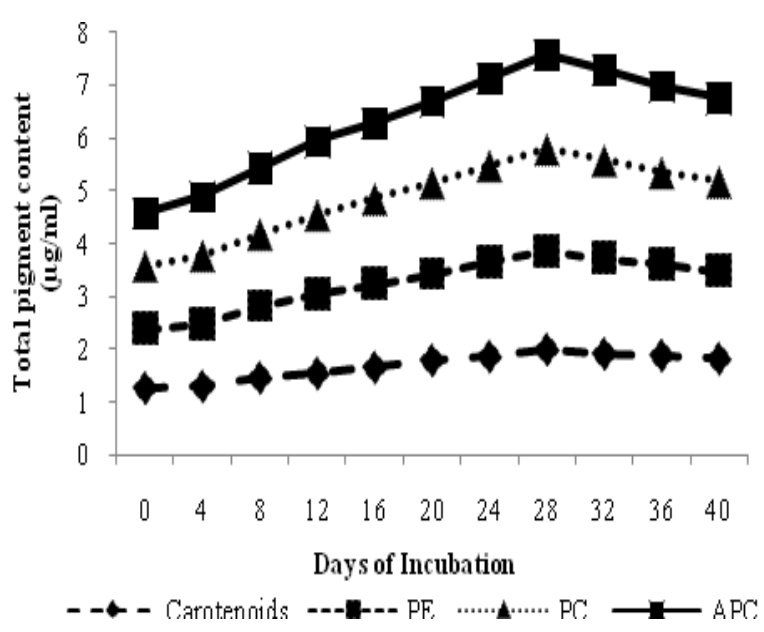

(c)

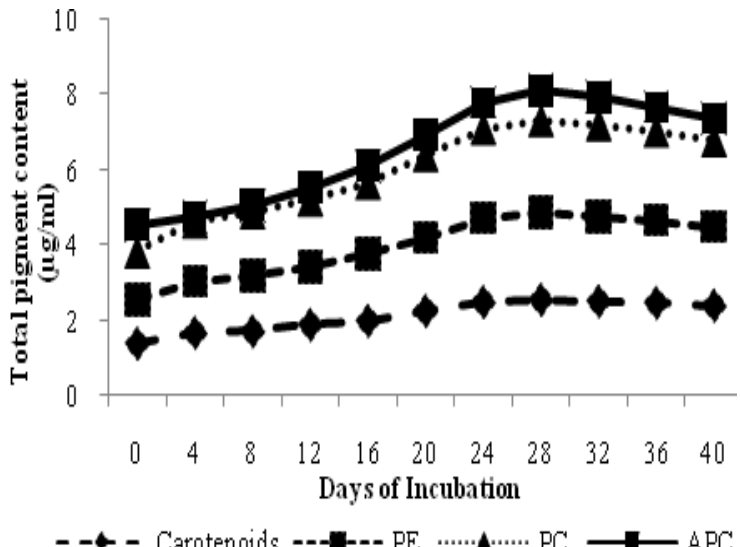

(e)

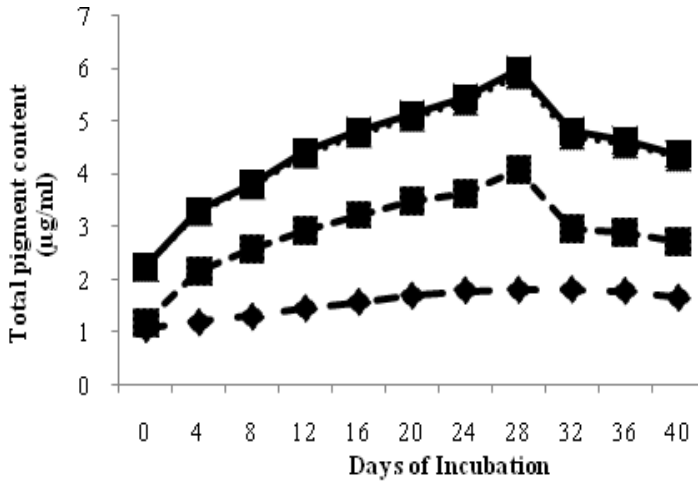

(b)

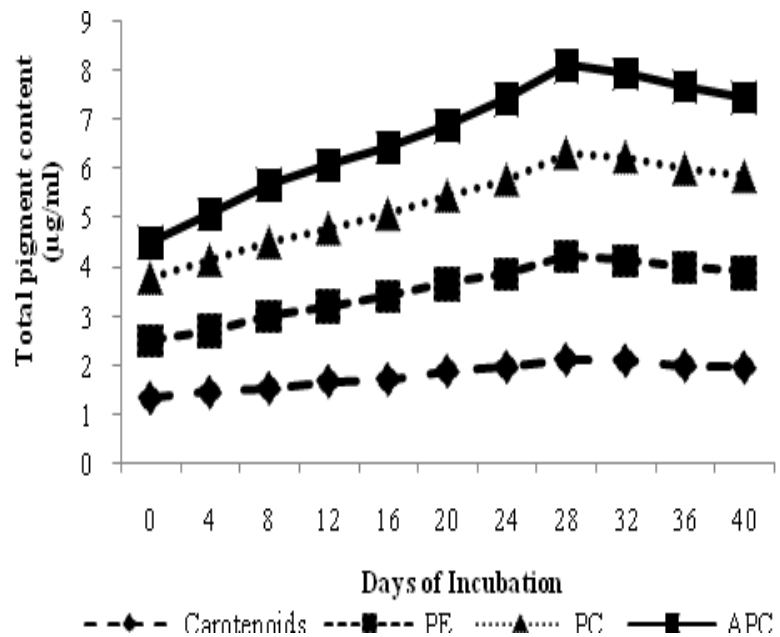

(d)

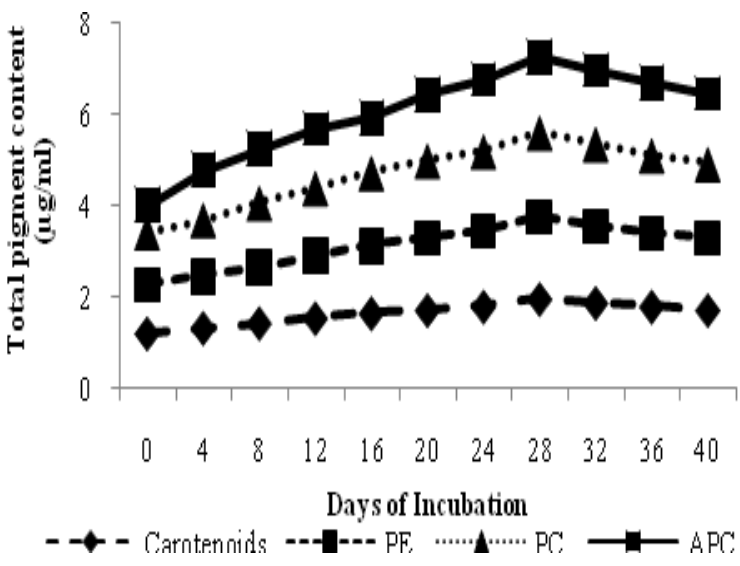

(f) 
Fig.4 Graph showing temporal variations of cellular carbohydrate and extracellular polysaccharide content in following sub-aerial Cyanobacteria species (a) Scytonema ocellatum; (b) Scytonema hofman-bangii; (c) Scytonema hyalinum; (d) Scytonema bohneri; (e) Tolypothrix rechingeri; and (f) Westiellopsis prolifica. Data are mean values $\pm \operatorname{SD}(n=3)$

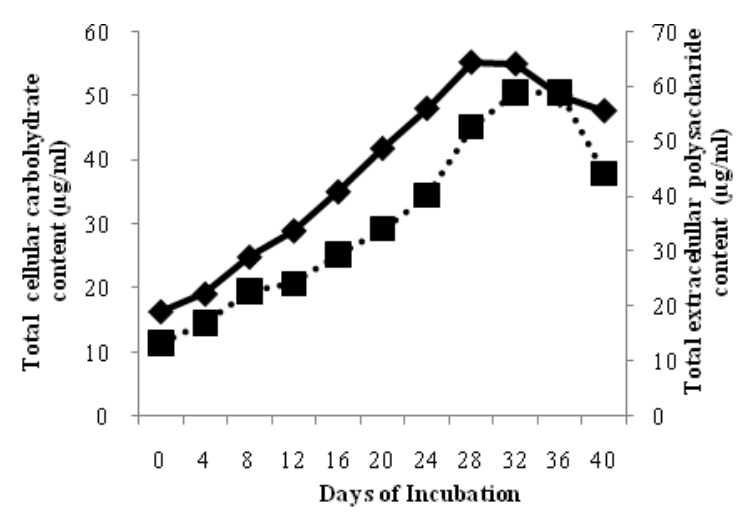

(a)

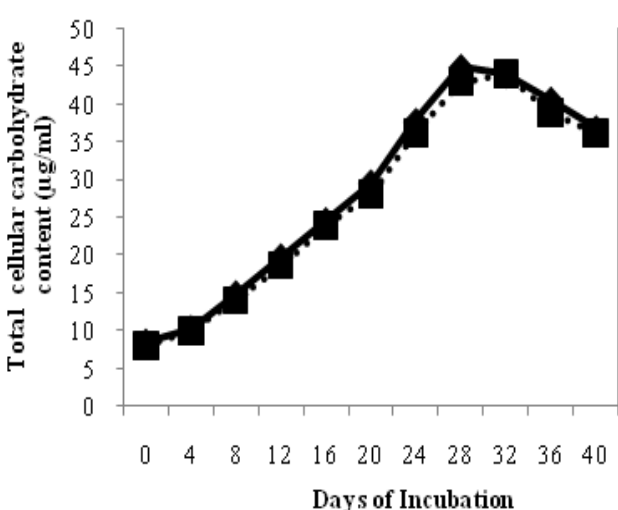

$\longrightarrow$ Cellular carbohydrates …...... Extracellular Poly saccharides

(c)

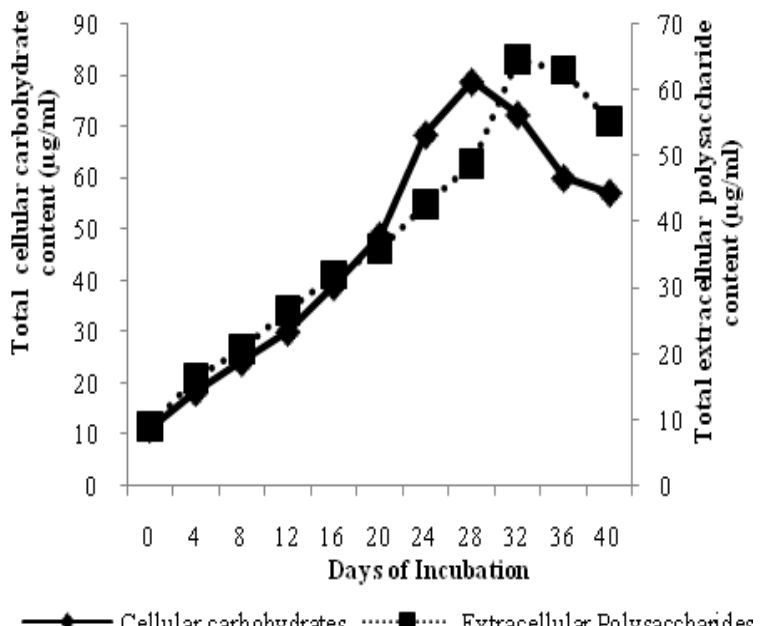

(e)

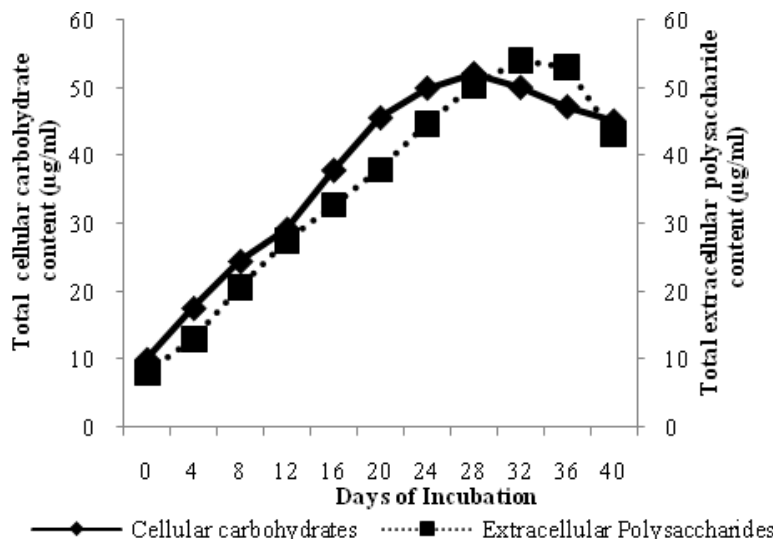

(b)

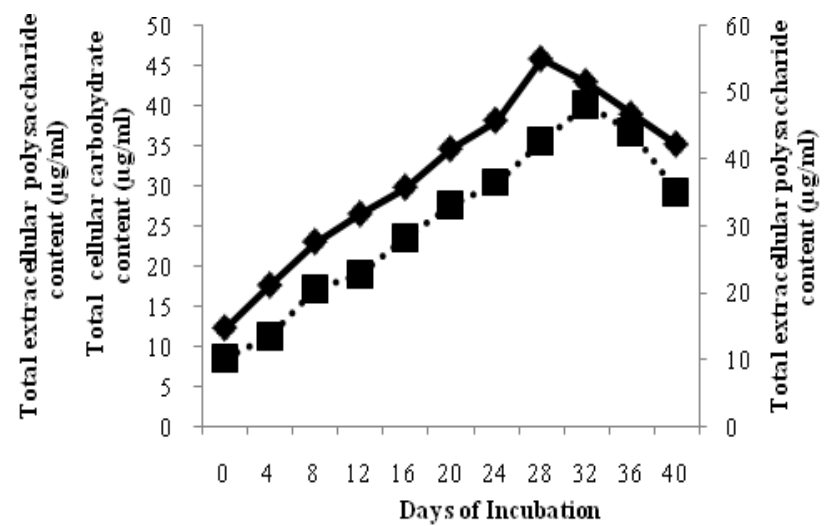

$\longrightarrow$ cellular carbohydrates ……... Extracellular Polysaccharides (d)

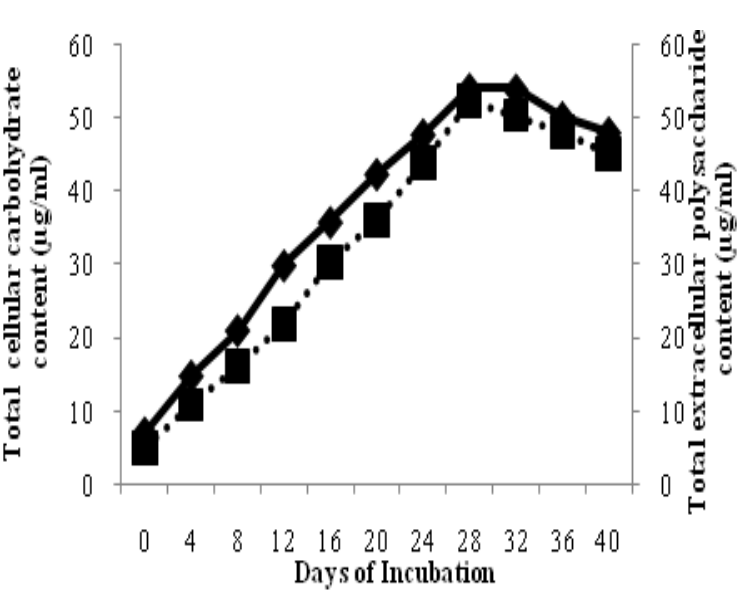

$\longrightarrow$ Cellular carbohydrates …........ Extracellular Polysaccharides

(f) 
Cyanobacteria in general posse's phycobiliproteins, water soluble pigments that can be divided into three main groups according to their structures: PC, PE and APC (Abd El Baky and El Baroty, 2013). Among them, phycocyanin (PC) and phycoerythrin (PE) are commercially importance over synthetic colour as they are environmental friendly, non-toxic and non-carcinogenic as recorded from extracts extracted from Spirullina sp., Synechococcus sp., Oscillatoria quadripunctulata and Anabaena (Borowitzka, 1994) etc. These natural photosynthetic pigments have already been commercialized as products in the food industry, as natural dyes, in fluorescence microscopy, cosmetics and in pharmaceuticals applications. In this view, present investigation were carried out to analyze the total phycobiliproteins including PC, APC and $\mathrm{PE}$ in six sub-aerial cyanobacteria strains isolated from different sub-aerial sites. The results of phycobilin analyses of investigated sub-aerial cyanobacteria showed total PBPs ranged from $2.28-5.28 \mu \mathrm{gml}^{-1}$ in Scytonema ocellatum, $1.16-4.15 \mu \mathrm{gml}^{-1}$ in Scytonema hofman-bangii, $\quad 3.29-5.58 \mu \mathrm{gml}^{-1}$ in Scytonema hyalinum, $3.15-5.99 \mathrm{gml}^{-1}$ in Scytonema bohneri, $3.14-5.59 \mu \mathrm{gml}^{-1}$ in Tolypothrix rechingeri and $2.28-2.28 \mu \mathrm{gml}^{-1}$ in Westiellopsis prolifica respectively have been depicted in Figure 3(a-f). The major PBPs were found in Scytonema and Tolypothrix followed by Westiellopsis. Total six isolates, three species showed phycocyanin to be the most dominant phycobiliproteins with maximum value recorded in Tolypothrix rechingeri $(2.46 \mu \mathrm{g}$ $\left.\mathrm{ml}^{-1}\right)$, Scytonema bohneri $\left(2.10 \mu \mathrm{gml}^{-1}\right)$ and lowest in Scytonema hofman-bangii. On the contrary, Scytonema hofman-bangii recorded highest phycoerythrin $\left(2.28 \mu \mathrm{gml}^{-1}\right)$. Low contents of PCand APC was recorded in Scytonema hofman-bangii. The high content of APC content were found in Scytonema bohneri and Westiellopsis prolifica. The species namely, Tolypothrix rechingeri, Scytonema bohneri and Scytonema hyalinum showed similar trends in increase in the contents of PC followed by APC and PE respectively. The study conducted by Patel et al., (2005) showed that the contents of three PBPs on three species of cyanobacteria namely, Spirulina sp., Phormidium sp., and Lyngbya sp. Decreased in the order of PC, APC and PE. Pandey and Pandey (2013) reported the high content of PC followed by APC and PE in Oscillatoria proboscidea, $O$. Limosa, O. Irrigua, Phormidium foveolarum, P. Tenue, Anabaena oryzae, Rivularia aquatica and Hapalosiphon sp. This kind of similar variation in the individuals was observed in present study. In study of Sekar and Chandramohan (2008), PBPs have been described as the strong antioxidants, and PC and APC were reported for antiviral and antifungal activities. Several investigators showed anti-inflammatory activities of PBPs of phytoplankton (Abd El Baky and Baroty, 2013; Jensen, 2015). The results of this investigation revealed that sub-aerial Cyanobacteria are able to synthesis photosynthetic pigment which can be used in various biotechnological applications.

The total cellular carbohydrates content analysis showed that the highest content in Tolypothrix rechingeri $\left(78.76 \mu \mathrm{gml}^{-1}\right)$ on $28^{\text {th }}$ day of incubation followed by Scytonema ocellatum, Westiellopsis prolifica and Scytonema hofman-bangii $\quad\left(55.23 \mu \mathrm{gml}^{-1}\right.$, $54.1 \mu \mathrm{gml}^{-1}$ and $52.12 \mu \mathrm{gml}^{-1}$ respectively) while the species Scytonema bohneri and $S$. hyalinum species exhibit low cellular carbohydrate content in comparison to control $\left(45.76 \mu \mathrm{gml}^{-1}\right.$ and $\left.44.9 \mu \mathrm{gml}^{-1}\right)$. However, released extracellular polysaccharides (EPS) in medium were recorded after $28^{\text {th }}$ day. Extracellular polysaccharides (EPS) content was found maximum during $32^{\text {th }}$ day growth. Tolypothrix rechingeri and Scytonema ocellatum $\left(64.54 \mu \mathrm{gml}^{-1}\right.$ and $\left.58.98 \mu \mathrm{gml}^{-1}\right)$ 
showed highest EPS content with comparison to other on 32th day of growth (Fig. 4b, c, d, f). Increased development of pigments are indicative of high photosynthetic activity and consequently, probable high accumulation of carbohydrate content in all the six organisms. During physical stress, microalgae tend to use available nutrients to preferentially produce carbohydrates instead of proteins (Rodolfi et al., 2009). According to studies reported by Shah et al., (2000), intracellular and extracellular carbohydrates of cyanobacteria can be used in food packing and metal removal industries.

\section{Phytochemical characterization}

Phytochemical characterization of the six subaerial Cyanobacteria isolates were screened for its photochemistry constituents using aqueous and different organic solvents like hexane, benzene, chloroform, acetone and methanol based on polarity. The presence of phytochemical compounds such as alkaloids, glycosides, phenol, flavonoid, Quinones, terpenoids, tannin, steroids coumarins in the six different extracts of sub-aerial cyanobacteria is shown in following Table 2. The results indicated that among all the six strains, the species which belong to genus Scytonema isolated from different substratum of building facades and monument showed the highest presence of alkaloids and phenolic contents as compared to other phytochemical constituents in hexane, benzene, chloroform, acetone and methanol extracts shown in Table -2 . The presence of alkaloids in the genus indicates that it can be commercialized particularly for pharmaceutical application and the phenolic compounds particularly the complex flavonoid are important class of antioxidants can be used for industrial application.

In general, cyanobacteria species investigated here displayed a potential use for humans as other species has already demonstrated. However, more attention must be given for sub-aerial cyanobacteria, commonly found in extreme environment. Amongst the strains analyzed, Tolypothrix rechingeri (Wille) Geitler, Scytonema ocellatum (Lyngbya), Scytonema bohneri Gardner, Scytonema hofman-bangii Agardh ex Silva and Scytonema hyalinum showed higher production of the pigments, proteins, carbohydrate and EPS content but variation was observed from species to species. Thus, further exploratory studies should be done with sub-aerial cyanobacteria species through genetic approaches and mass cultivation technology to improve their potential for industrial and biotechnological applications towards human welfare. In addition, other investigations with more precise analyses of biochemical composition of them should also be made in order to create more detailed information and, thus, favour future applications.

The present study highlights the importance of combined morphological, biochemical and phytochemical characterization of the potent isolates from Bhubaneswar and Puri of Odisha. The species isolated in the present work was found to possess a higher phycocyanin content compared to other phycobiliproteins pigments. High soluble protein and cellular carbohydrate content found in these sub-aerial cyanobacteria contribute to the nutritional value of the species. The present findings indicate the positive response in case of alkaloids, phenolic and flavonoids in these isolates which possess immense antimicrobial activity for application towards pharmaceutical industry. However, few species is popularized in worldwide due to limitation in the economic production of cyanobacteria products in the industrial and pharmaceutical scale. Thus, intensive research is needed for the need of potent cyanobacteria from these 
extreme habitats towards large production of the products with non-toxic from these isolates which could be used for further studies.

\section{Acknowledgement}

The authors thank Science and Technology Department, Govt. of Odisha for financial support for the major project research work. We also thank the Head of the Department of Botany, College of Basic Science and Humanities, Orissa University of Agriculture and Technology for providing facilities to conduct this research.

\section{References}

Abd El Baky, H. H. and El-Baroty, G.S. 2013. Healthy Benefit of Microalgal Bioactive Substances. Journal of Aquatic Science, 1(1): 11-23.

Adhikary, S. P., Keshari, N., Urzi, C. and De Phillipis, R. 2015. Cyanobacteria in biofilms on stone temples of Bhubaneswar, Eastern India. Algalogical Studies, 147: 67-93.

Asthana, R. K., Tripathi, M. K., Srivastava, A., Singh, A. P., Singh, S. P. and Nath, G. 2009. Isolation and identification of a new antibacterial entity from the Antarctic Cyanobacterium Nostoc CCC 537. Journal of Applied Phycology, 21(1): 81-88.

Balder, H. F., Vogel, J., Jansen, M.C., Weijenberg, M.P., Van den Brandt, P.A., Westenbrink, S., Van der Meer, R. and Goldbohm, R. A. 2006. Heme and chlorophyll intake and risk of colorectal cancer in the Netherlands cohort study. Cancer Epidemiology Biomarkers and Prevention, 15: 717-725.

Becker, E.W. 1994. Microalgae: biotechnology and microbiology. Cambridge University Press.
Bennett, A. and Bogorad, L. 1973. Complimentary Chromatic Adaptation in a Filamentous Blue Green Alga. The Journal of Cell Biology, 58 (2): 419.

Borowitzka, M. A. 1994. Products from Algae. In: Phang S.M., Lee K., Borowitzka M.A. and Whitton B. (eds.), Algal Biotechnology in the Asia-Pacific Region. Institute of Advanced Studies, University of Malaya: Kuala Lumpur. pp. 5-15.

Ciferri, O. And Tiboni, O. 1985. The biochemistry and industrial potentials of Spirulina. Annual Review of Microbiology, 39: 503 - 526.

Deb, S., Rout, J., Sengupta, M. and Chakraborty, B. 2015. Biochemical profile and antimicrobial activity of a cyanobacterium, Scytonema tolyprothrichoides isolated from Acidic Rice field soil of Cachar. International Journal of Life Science and Pharma Research, 5 (2): 21- 31.

Desikachary, T.V. 1959. Cyanophyta. ICAR, New Delhi. pp. 686.

Dufossé, L., Galaup, P., Yaron A., Arad, S. M., Blanc, P., Murthy, K.N.C. and Ravishankar, G.A. 2005. Microorganisms and microalgae as sources of pigments for food use: a scientific oddity or an industrial reality? Trends Food Science Technology, 16:389-406.

Enzing, C., Ploeg, M. Barbosa, M. and Sijitsma, L. 2014. Microalgae-Based Products for the Food and Feed Sector: An Outlook for Europe. Jrc Scientific Reports. - Luxembourg.

Ferruzzi, M.G., Blakeslee, J. 2007. Digestion, absorption, and cancer preventative activity of dietary chlorophyll derivatives. Nutrition Research, 27: 112.

Gantar, M. and Svircev, Z. 2008. Microalgae and cyanobacteria: food for thought. Journal of Phycology, 44: 260 -268. 
Gouveia, L., Batista, A.P., Sousa, I., Raymundo, A. and Bandarra, N.M. 2008. Microalgae in novel food products, In: Papadopoulos, K.N. (ed.), Food chemistry research developments. Nova Science Publishers, New York. 137.

Gressler, V., Fujii, M. T., Martins, A. P., Colepicolo, P., Mancini-Filho, J., and Pinto, E. 2011. Biochemical composition of two red seaweed species grown on the Brazilian coast. Journal of the Science of Food and Agriculture, 91: 1687-1692.

Gutierrez, M., Suyama, T.L., Engene, N., Wingerd, J.S., Matainaho, T. and Gerwick W.H. 2008. Apratoxin D, a potent cytotoxic cyclodepsipeptide from Papua New Guinea collections of the marine cyanobacteria Lyngbya majuscula and Lyngbya sordida. Journal of Natural Products, 71: 10991103.

Herbert, D., Phipps, $\mathrm{Pj}$, and Strange, Re. 1971. Chemical Analysis of Microbial Cells. In: Methods In Microbiology Vol. (V) $B$ (Ed.) Morris Jr, Ribbons Dw. New York: Academic Press, 209-234.

Hertzberg, S., Liaaen-Jensen, S., Siegelman, H.W. 1971. The carotenoids of bluegreen algae. Phytochemistry, 10: 3121 3127.

Jensen, A. 1978. Chlorophylls and Carotenoids. In: Hellebust Ja, Craige Is. (Ed). Hand Book Of Phycological Methods. Physiological and Biochemical Methods. Cambridge: Cambridge University Press. 59-70.

Jensen, G.S., Attridge, V.L., Beaman, J.L., Guthrie, J., Ehmann, A. and Benson, K.F. 2015. Antioxidant and antiinflammatory properties of an aqueous cyanophyta extract derived from Arthrospira platensis: contribution to bioactivities by the non-phycocyanin aqueous fraction. Journal of Medicinal Food. 18: 535-41.

Keshari, N. and Adhikary, S.P. 2014. Diversity of cyanobacteria on stone monuments and building facades of India and their phylogenetic analysis. International Biodeterioration and Biodegradation, 90: 45-51.

Komárek, J. and Hauer, T. 2015. CyanoDB.cz-On-line database of cyanobacterial genera.World-wide electronic publication, University of South Bohemia and Institute of Botany.

Lowry, O. H., Rosebrough N. J., Farr A. L. and Randall R. J. 1951. Protein measurement with the Folin phenol reagent. Journal of Biological Chemistry, 193: 265-275.

Mckinney, G. 1941. Absorption of Light by Chlorophyll Solutions. Journal of Bioogical Chemistry 221: 315-322.

Nishiyama, Y. and Murata, N. 2014. Revised scheme for the mechanism of photo inhibition and its application to enhance the abiotic stress tolerance of the photosynthetic machinery. Applied Microbiology Biotechnology, 98:87778796.

Pandey, M. 2006. Nutrient Modulated Alkaline Phosphatase and Associated Processes in Diayotrophic Cyanobacteria. Polish Journal of Microbiology, 55(1): 53-62.

Pandey, V.D., Pandey, A. and Sharma, V. 2013. Biotechnological applications of cyanobacterial phycobiliproteins. International Journal of Current Microbiology and Applied Sciences. 2(9): 89-97.

Patel, A., Mishra, S., Pawar, R. and P.K. Ghosh. 2005. Purification and characterization of C-phycocyanin from cyanobacterial species of marine and freshwater habitat. Protein Expression and Purification, 40: 248-255. 
Paul, A. and Rout, J. 2017. Biochemical evaluation of some cyanobacterial strains isolated from the lime sludge wastes of a Paper Mill in Southern Assam (India). Phykos 47 (1): 8-15.

Rai, S.V. and Rajashekhar, V. 2015. Antioxidant potential of eight species of cyanobacteria isolated from Arabian Sea coast of Karnataka. Journal of Chemical and Pharmaceutical Research, 7(12): 938-942.

Rajeshwari, KR. and Rajashekhar, M. 2011. Biochemical composition of seven species of cyanobacteria isolated from different aquatic habitats of Western Ghats, Southern India. Brazilian. Archives Biology and Technology, 54(5).

Rippka, R., Deruelles, J., Waterbury, J.B., Herdman, M. and Stanier, R.Y. 1979. Generic assignments, strain histories and properties of pure culture of cyanobacteria. Journal of General Microbiology, 111: 1-61.

Rodolfi, L., G.C. Zitelli, N. Bassi, G. Padovani, N. Biondi, G. Bonini \& M.R. Tredici. 2009. Microalgae for oil: strain selection, induction of lipid synthesis and outdoor mass cultivation in a lowcost photobioreactor. Biotechnology Bioengineering, 102: 100-112.

Rossi, F., Potrafka, R. M., Garcia-Pichel, F. and De Philippis, R. 2012. The role of the exopolysaccharides in enhancing hydraulic conductivity of biological soil crusts, Soil Biology and Biochemistry 46: 33.

Sekar, S. and Chandramohan, M. 2008. Phycobiliproteins as a commodity trends in applied research, patents and commercialization. Journal of Applied Phycology, 20: 113-136.

Shah, V.; Ray, A.; Garg, N. and Madamwar, D. 2000.Characterization of the extracellular polysaccharide produced by the marine cyanobacterium Cyanothece ATCC 51142 and its exploitation toward metal removal from solutions. Current Microbiology, 40: $274-278$.

Skulberg, O.M. 2000. Microalgae as a source of bioactive molecules experience from cyanophyte research. Journal of Applied Phycology, 12: 341- 348.

Takaichi, S. 2011 Carotenoids in Algae: Distributions, Biosyntheses and Functions. Marine Drugs, 9: 11011118.

Tonetto, A F., Oliveira K.S. M. and Domingues, T. M. 2014. Analysis of biochemical composition of three stream macro algae species. International Journal of Applied Science and Technology, 4, 5.

\section{How to cite this article:}

Pattnaik, S. and Samad, L.K. 2018. Morphological and Biochemical Characterization of SubAerial Cyanobacteria Isolated from Building Facades and Monuments of Odisha. Int.J.Curr.Microbiol.App.Sci. 7(06): 556-571. doi: https://doi.org/10.20546/ijcmas.2018.706.064 